Electronic Supplemental Information for

\title{
Cadmium hydroxide: a missing non-noble metal hydroxide electrocatalyst for the oxygen evolution reaction
}

Xiang Chen, ${ }^{* \dagger \$}$ Haonan Wang, ${ }^{\dagger+}$ Ruru Meng, ${ }^{\dagger+}$ Bin Xia, ${ }^{\dagger+~ Z u j u ~ M a * \dagger \$ ~}$

$\dagger$ Key Laboratory of Metallurgical Emission Reduction \& Resources Recycling (Anhui University of Technology), Ministry of Education, Maanshan 243002, P. R. China

*School of Materials Science and Engineering, Anhui University of Technology, Maanshan 243002, P. R. China

$\S$ Key Laboratory of Green Fabrication and Surface Technology of Advanced Metal Materials (Anhui University

of Technology), Ministry of Education, Maanshan 243002, P. R. China

Email:*chxiang@mail.ustc.edu.cn

*zjma@outlook.com

\section{Contents}

S1. Experimental section.

S2. Side views of the optimized geometries of relevant species during $\mathrm{OER}$ on $\mathrm{Cd}(\mathrm{OH})_{2}$ (001) surface.

S3. Side views of the optimized geometries of relevant species during OER on $\mathrm{Co}(\mathrm{OH})_{2}$ (001) surface.

S4. SEM images and TEM images $\mathrm{Cd}(\mathrm{OH})_{2}$ prepared by using $\mathrm{CdCl}_{2}$ and $\mathrm{CdSO}_{4}$ as the precursors.

S5. XRD patterns of $\mathrm{Cd}(\mathrm{OH})_{2}$ prepared by using $\mathrm{CdCl}_{2}$ and $\mathrm{CdSO}_{4}$ as the precursors.

S6. XPS spectra of the prepared $\mathrm{Cd}(\mathrm{OH})_{2}$ catalysts.

S7. The OER electrocatalytic activities of $\mathrm{Cd}(\mathrm{OH})_{2}$ prepared by using $\mathrm{CdCl}_{2}$ and $\mathrm{CdSO}_{4}$ as the precursors.

S8. $\mathrm{N}_{2}$ adsorption-desorption isotherms of the $\mathrm{Cd}(\mathrm{OH})_{2}$ catalysts.

S9. XRD pattern of $\mathrm{Cd}(\mathrm{OH})_{2}$ catalyst after galvanostatic stability test.

S10. SEM and TEM images of $\mathrm{Cd}(\mathrm{OH})_{2}$ catalyst after galvanostatic stability test.

S11. SEM image of $\mathrm{Co}(\mathrm{OH})_{2}$.

S12. The OER electrocatalytic activities of $\mathrm{Fe}(\mathrm{OH})_{3}$ and $\mathrm{Ni}(\mathrm{OH})_{2}$.

S13. CV curves of $\mathrm{Cd}(\mathrm{OH})_{2}$ and $\mathrm{Co}(\mathrm{OH})_{2}$ at different scan rates. 


\section{S1. Experimental Section}

\section{Materials}

$\mathrm{Cd}\left(\mathrm{NO}_{3}\right)_{2} \cdot 4 \mathrm{H}_{2} \mathrm{O}, \mathrm{Co}\left(\mathrm{NO}_{3}\right)_{2} \cdot 6 \mathrm{H}_{2} \mathrm{O}, \mathrm{Fe}\left(\mathrm{NO}_{3}\right)_{3} \cdot 9 \mathrm{H}_{2} \mathrm{O}, \mathrm{Ni}\left(\mathrm{NO}_{3}\right)_{2} \cdot 6 \mathrm{H}_{2} \mathrm{O}, \mathrm{KOH}, \mathrm{NaOH}, \mathrm{HCl}(\approx 37$ wt $\%)$ and $\mathrm{Ni}$ foam were purchased from China National Pharmaceutical Industry Corporation $\mathrm{Ltd} \mathrm{RuO}_{2}$ $(99.9 \%)$ was purchased from Aladdin. Except the Ni foam was washed with diluted hydrochloric acid, water and ethanol successively, other materials were used as received without further treatment.

\section{Synthesis of metal hydroxides}

The metal hydroxides $\mathrm{Cd}(\mathrm{OH})_{2}, \mathrm{Co}(\mathrm{OH})_{2}, \mathrm{Fe}(\mathrm{OH})_{3}$ and $\mathrm{Ni}(\mathrm{OH})_{2}$ were prepared by drop by drop adding aqueous solution of sodium hydroxide to an aqueous solution of metal nitrates $\mathrm{Cd}\left(\mathrm{NO}_{3}\right)_{2}$, $\mathrm{Co}\left(\mathrm{NO}_{3}\right)_{2}, \mathrm{Fe}\left(\mathrm{NO}_{3}\right)_{3}$ and $\mathrm{Ni}\left(\mathrm{NO}_{3}\right)_{2}$ under mild stirring, respectively. The products were washed several times with deionized water and dried in oven at $60{ }^{\circ} \mathrm{C}$ for $12 \mathrm{~h}$, and the metal hydroxides were obtained finally. The $\mathrm{Cd}(\mathrm{OH})_{2}$ using other cadmium salts $\left(\mathrm{CdCl}_{2}\right.$ and $\left.\mathrm{CdSO}_{4}\right)$ as the precursor also were prepared by using the same method as $\mathrm{Cd}\left(\mathrm{NO}_{3}\right)_{2}$ as the precursor.

\section{Measurements and Characterization.}

$\mathrm{X}$-ray powder diffraction patterns were characterized on an X-ray diffractometer with $\mathrm{Cu} \mathrm{K} \alpha$ radiation (40 $\mathrm{kV}, 30 \mathrm{~mA}, \lambda=0.154 \mathrm{~nm}$ ) at a scan rate of $5^{\circ} \mathrm{min}^{-1}$. The morphology characterizations of the samples were performed using a field-emission scanning electron microscope (SEM) (JEOL JSM6335) operating at 20 $\mathrm{kV}$. Transmission electron microscopy (TEM) and element mapping measurements were carried out using a JEOL JEM 2100 system operating at $200 \mathrm{kV}$. X-ray photoelectron spectroscopy (XPS) was carried out using an ESCALAB 250 X-ray photoelectron spectrometer (Thermo-VV Scientific) with Al Ka X-ray radiation. Brunauer-Emmett-Teller (BET) surface area analysis were carried out on ASAP 2460 instrument (Micromeritics, USA).

\section{Electrochemical Measurements}

The electrochemical OER measurements were carried out at room temperature in a three-electrode glass cell connected to an electrochemical workstation (CHI 660e, $\mathrm{CH}$, Shanghai.). $10 \mathrm{mg} \mathrm{Cd}(\mathrm{OH})_{2}, \mathrm{Co}(\mathrm{OH})_{2}$ $\mathrm{Fe}(\mathrm{OH})_{3}, \mathrm{Ni}(\mathrm{OH})_{2}$ or $\mathrm{RuO}_{2}$ catalyst and $60 \mu \mathrm{L} 5 \mathrm{wt} \%$ Nafion were added into $2 \mathrm{~mL}$ isopropanol and ultrasounded for $1 \mathrm{~h}$. Then $10 \mu \mathrm{L}$ above solution was droped in Ni foam, which was used as the work electrode (geometric area is $0.25 \mathrm{~cm}^{2}$ ). A platinum electrode and a saturated $\mathrm{Ag} / \mathrm{AgCl}$ were used as counter and reference electrode, respectively. Freshly prepared $1 \mathrm{M} \mathrm{KOH}$ aqueous solution (PH=13.9) was used as the electrolyte. Polarization curves were obtained using linear sweep voltammetry (LSV) with a scan rate of $2 \mathrm{mV} / \mathrm{s}$. All polarization curves were corrected for the iR compensation. The electrochemical impedance spectroscopy (EIS) was obtained in $1 \mathrm{M} \mathrm{KOH}$ solution by applying an AC voltage of $5 \mathrm{mV}$ amplitude at an applied voltage $1.5 \mathrm{~V}$ vs. RHE in the frequency range of $0.01 \mathrm{~Hz}-100 \mathrm{kHz}$.

\section{Calculation methods}

Our calculations on the pristine $\mathrm{Co}(\mathrm{OH})_{2}$ and $\mathrm{Cd}(\mathrm{OH})_{2}(001)$ surface were performed using the plane-wave basis Vienna Ab-initio Simulation Package (VASP) code ${ }^{\mathrm{S} 1-\mathrm{S} 3}$. The projected augmented wave $(\mathrm{PAW})^{\mathrm{S} 4}$ potentials with the valence states $1 s$ for $\mathrm{H}, 2 s$ and $2 p$ for $\mathrm{O}, 3 d$ and $4 s$ for Co, and $4 d$ and $5 s$ for Cd were 
used to treat the core-valence interaction. The PBE functional ${ }^{\mathrm{S} 5}$ was chosen for the structural optimization in this work. The vacuum region was kept at $15 \AA$, which was thick enough to avoid artificial interaction. A $\Gamma$-centered $9 \times 9 \times 1$ Monkhorst-Pack k-point grid and a cutoff energy of $450 \mathrm{eV}$ were found to get convergent total and adsorption energies. The geometries were fully relaxed until the maximal residual force was less than $0.02 \mathrm{eV} / \AA$. The $\mathrm{Co}(\mathrm{OH})_{2}$ and $\mathrm{Cd}(\mathrm{OH})_{2}(001)$ surfaces were modeled using a slab with a $2 \times 2$ cell in the surface direction and two atomic layers in the normal direction 1 . The bottom layer was fixed at the bulk position in the optimization of slab models.

We modeled the OER using the method developed by Norskov and coworkers, ${ }^{\mathrm{S} 6}, \mathrm{~S} 7$ who have studied the water oxidation on different metal oxide surfaces, such as $\mathrm{TiO}_{2}, \mathrm{RuO}_{2}$, and $\mathrm{IrO}_{2}$. Free energy change $\Delta \mathrm{G}_{0}=$ $\Delta \mathrm{E}+\Delta \mathrm{ZPE}-\mathrm{T} \Delta \mathrm{S}$, with $\Delta \mathrm{E}$ denoting the total self-consistent energy change (reaction energy) derived from DFT calculations, $\triangle \mathrm{ZPE}$ indicating the differences in zero-point energies, and $\Delta \mathrm{S}$ indicating the change of entropy. ZPE for the OER intermediates were obtained from the vibrational frequencies. For free gas-phase molecules, we obtained ZPE and S from thermodynamics database. ${ }^{\mathrm{S} 6}$ The free energy of $\mathrm{H}^{+}+\mathrm{e}^{-}$has been replaced by one-half of the chemical potential of the hydrogen molecule. Under the influence of a potential bias $\mathrm{U}$ and an infinite $\mathrm{pH}$, the free energy difference was shifted by $\Delta \mathrm{G}(\mathrm{U}, \mathrm{pH})=\Delta \mathrm{G}_{\mathrm{U}}+\Delta \mathrm{G}_{\mathrm{pH}}=-\mathrm{eU}-$ $k T \ln 10 \times \mathrm{pH}$.

S2. Side views of the optimized geometries of relevant species during $\mathrm{OER}$ on $\mathrm{Cd}(\mathrm{OH})_{2}(001)$ surface.
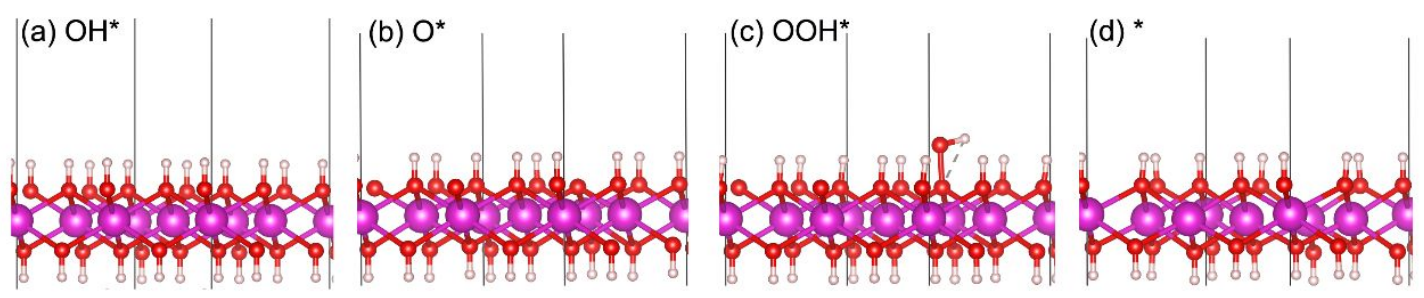

Figure S1. Side views of the optimized geometries of relevant species $\left(\mathrm{OH}^{*}, \mathrm{O}^{*}, \mathrm{OOH}^{*}\right.$ and $\left.*\right)$ during $\mathrm{OER}$ on $\mathrm{Cd}(\mathrm{OH})_{2}(001)$ surface.

\section{S3. Side views of the optimized geometries of relevant species during $\mathrm{OER}$ on $\mathrm{Co}(\mathrm{OH})_{2}(001)$} surface.
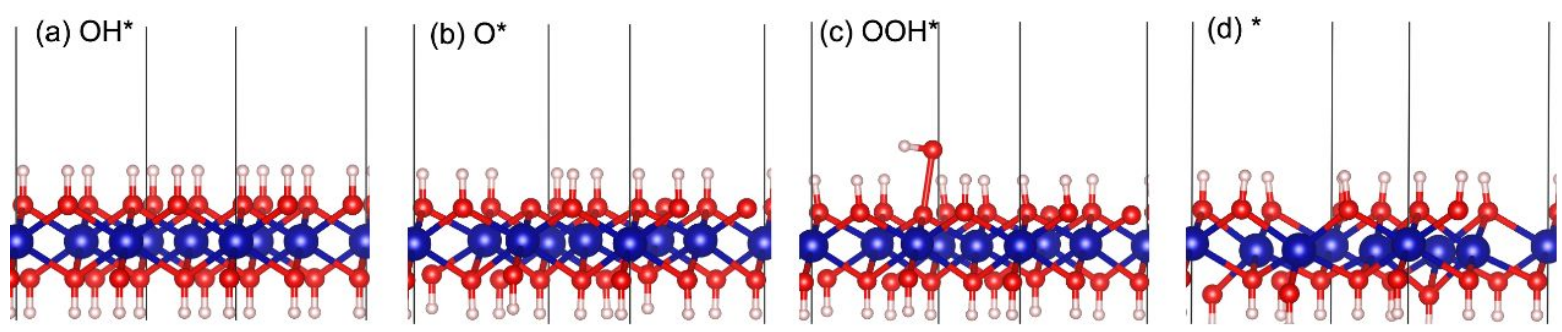

Figure S2. Side views of the optimized geometries of relevant species $\left(\mathrm{OH}^{*}, \mathrm{O}^{*}, \mathrm{OOH}^{*}\right.$ and $\left.*\right)$ during $\mathrm{OER}$ on $\mathrm{Co}(\mathrm{OH})_{2}(001)$ surface. 
S4. SEM images and TEM images $\mathrm{Cd}(\mathrm{OH})_{2}$ prepared by using $\mathrm{CdCl}_{2}$ and $\mathrm{CdSO}_{4}$ as the precursors.
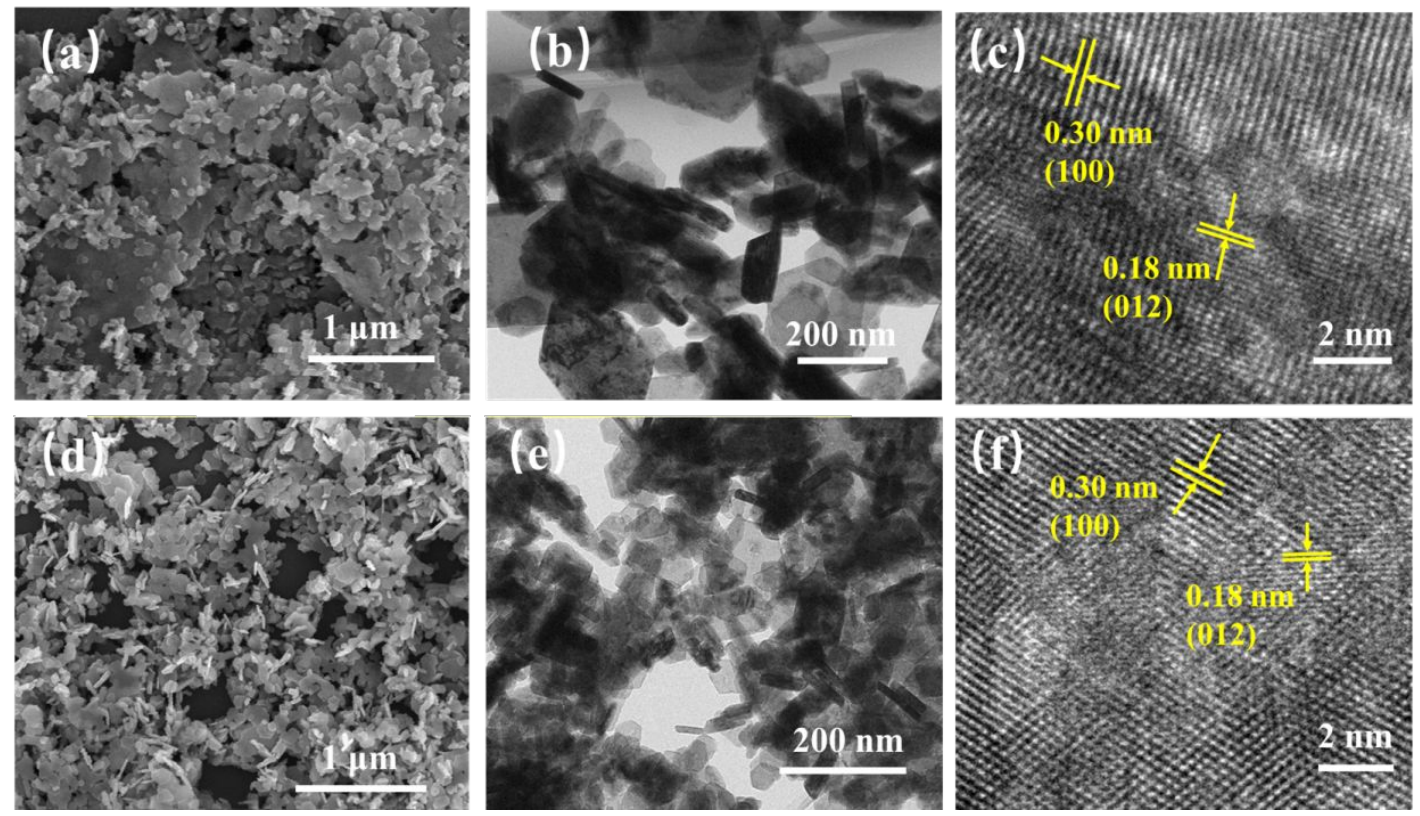

Figure S3. (a,d) SEM images, $(\mathrm{b}, \mathrm{e})$ TEM images and (c,f) HRTEM images of $\mathrm{Cd}(\mathrm{OH})_{2}$ prepared by using $\mathrm{CdCl}_{2}$ and $\mathrm{CdSO}_{4}$ as the precursors, respectively.

S5. XRD patterns of $\mathrm{Cd}(\mathrm{OH})_{2}$ prepared by using $\mathrm{CdCl}_{2}$ and $\mathrm{CdSO}_{4}$ as the precursors.

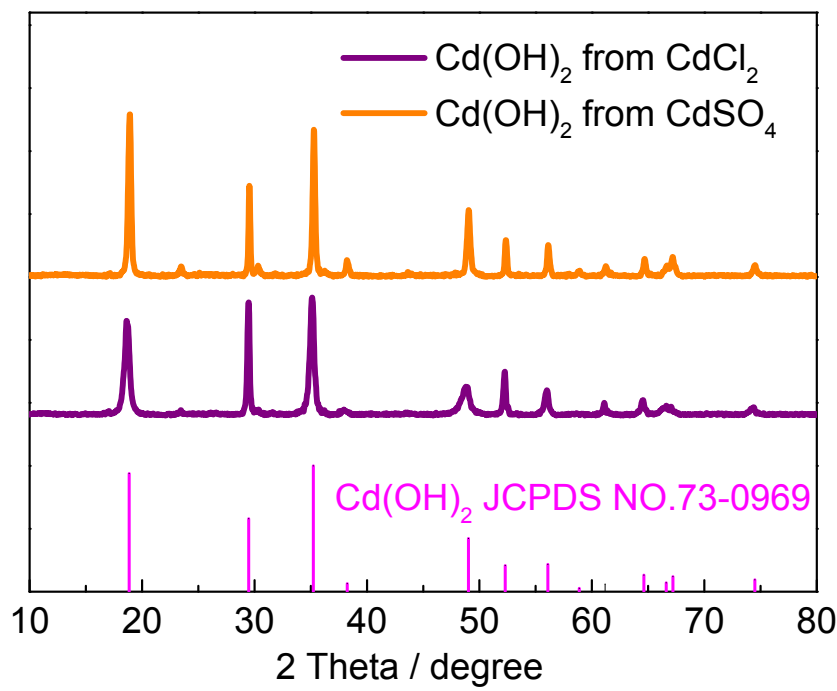

Figure S4. XRD patterns of $\mathrm{Cd}(\mathrm{OH})_{2}$ prepared by using $\mathrm{CdCl}_{2}$ and $\mathrm{CdSO}_{4}$ as the precursors. 
S6. XPS spectra of the prepared $\mathrm{Cd}(\mathrm{OH})_{2}$ catalysts.
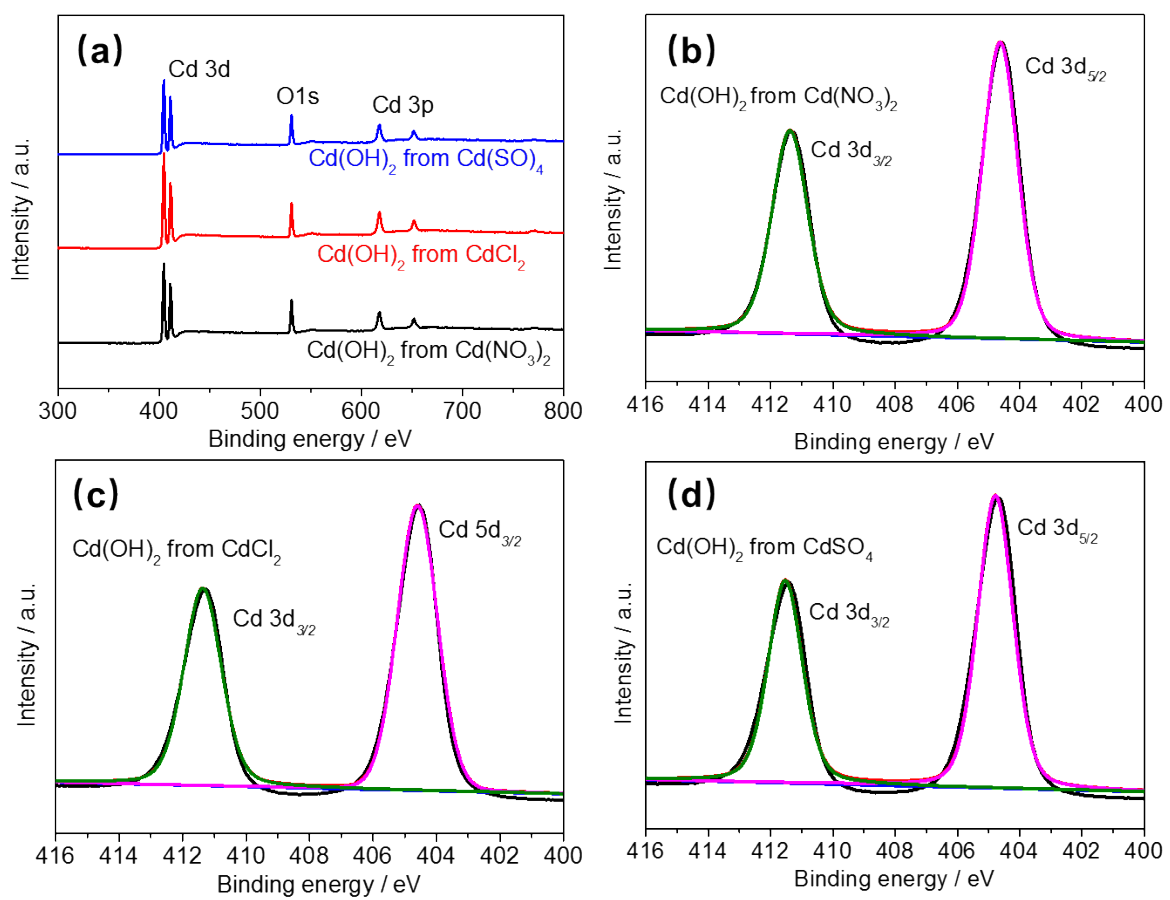

Figure S5. (a) XPS survey spectra and (b,c,d) high-resolution Cd 3d XPS spectra of $\mathrm{Cd}(\mathrm{OH})_{2}$ prepared from $\mathrm{Cd}\left(\mathrm{NO}_{3}\right)_{2}, \mathrm{CdCl}_{2}$ and $\mathrm{CdSO}_{4}$, respectively.

S7. The OER electrocatalytic activities of $\mathrm{Cd}(\mathrm{OH})_{2}$ prepared by using $\mathrm{CdCl}_{2}$ and $\mathrm{CdSO}_{4}$ as the precursors.

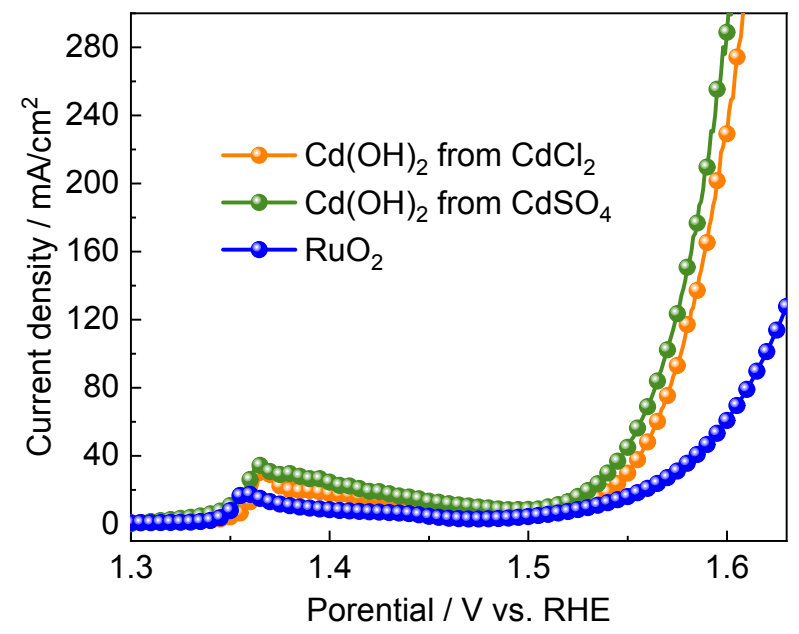

Figure S6. $\mathrm{LSV}$ curves of $\mathrm{Cd}(\mathrm{OH})_{2}$ prepared by using $\mathrm{CdCl}_{2}$ and $\mathrm{CdSO}_{4}$ as the precursors. 
S8. $\mathrm{N}_{2}$ adsorption-desorption isotherms of the $\mathrm{Cd}(\mathrm{OH})_{2}$ catalysts.

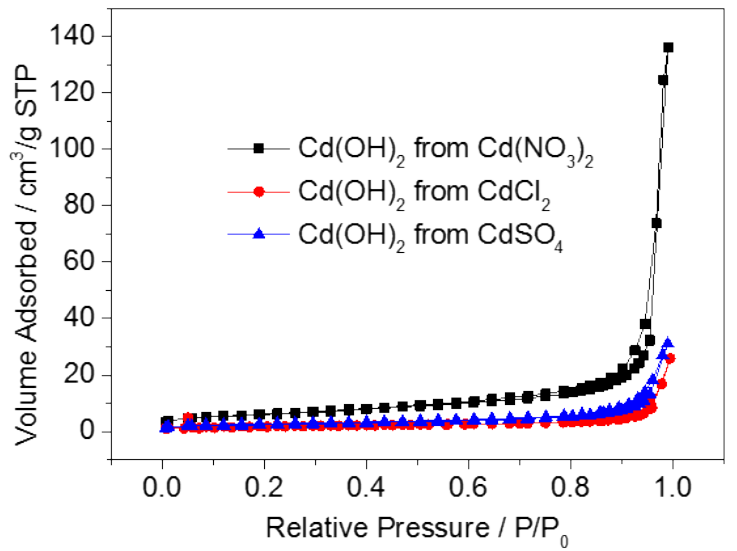

Figure S7. $\mathrm{N}_{2}$ adsorption-desorption isotherms of the $\mathrm{Cd}(\mathrm{OH})_{2}$ catalysts prepared by using $\mathrm{Cd}\left(\mathrm{NO}_{3}\right)_{2}, \mathrm{CdCl}_{2}$ and $\mathrm{CdSO}_{4}$ as the precursors.

S9. XRD pattern of $\mathrm{Cd}(\mathrm{OH})_{2}$ catalyst after galvanostatic stability test.

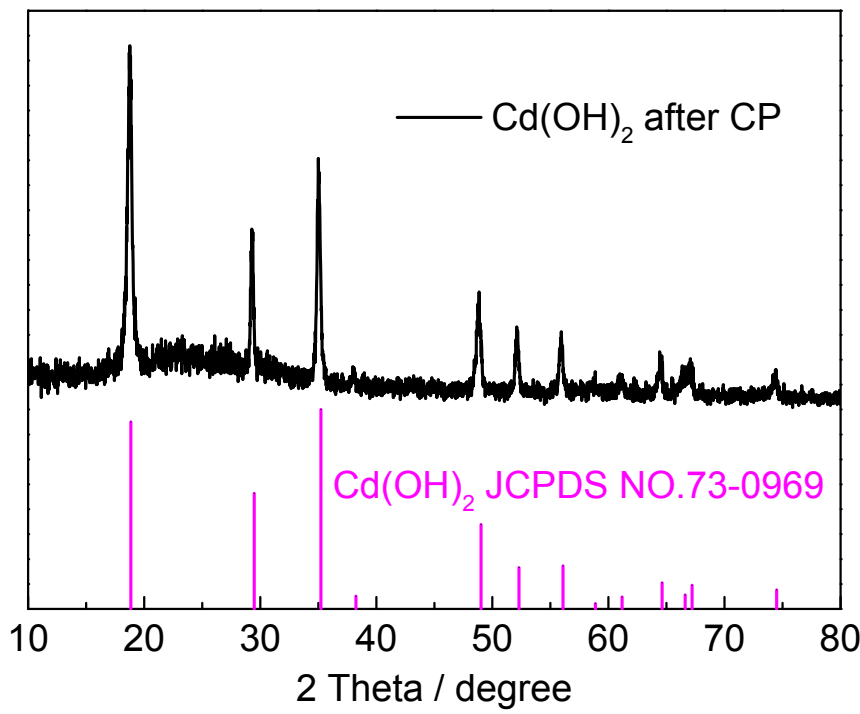

Figure S8. XRD pattern of $\mathrm{Cd}(\mathrm{OH})_{2}$ after chronopotentiometric $(\mathrm{CP})$ experiment. 
S10. SEM and TEM images of $\mathrm{Cd}(\mathrm{OH})_{2}$ catalyst after galvanostatic stability test.
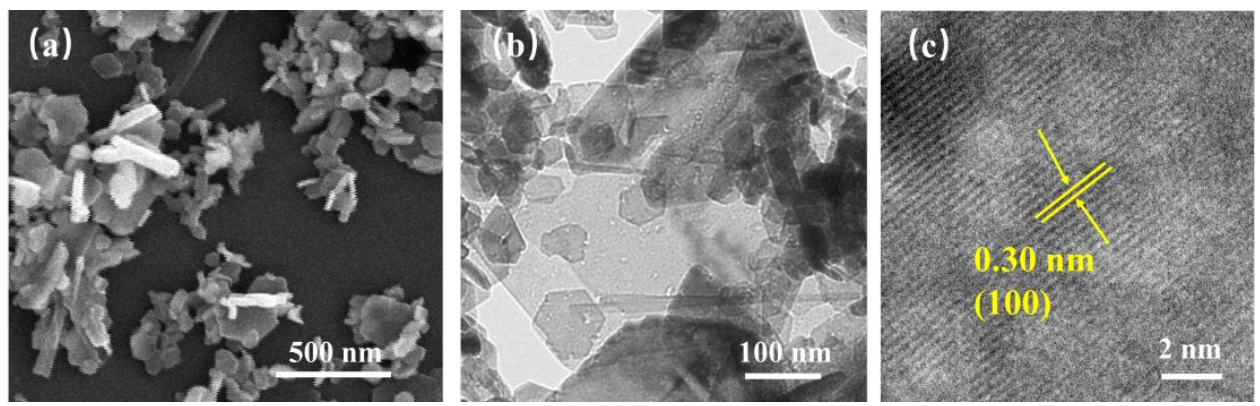

Figure S9. (a) SEM image, (b) TEM image and (c) HRTEM image of $\mathrm{Cd}(\mathrm{OH})_{2}$ catalyst after galvanostatic stability test.

S11. SEM image of $\mathrm{Co}(\mathrm{OH})_{2}$.

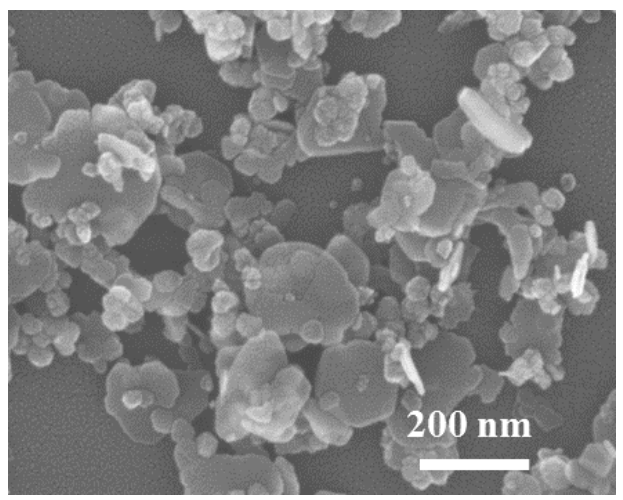

Figure S10. SEM image of $\mathrm{Co}(\mathrm{OH})_{2}$ prepared by using the same method as $\mathrm{Cd}(\mathrm{OH})_{2}$.

S12. The OER electrocatalytic activities of $\mathrm{Fe}(\mathrm{OH})_{3}$ and $\mathrm{Ni}(\mathrm{OH})_{2}$.

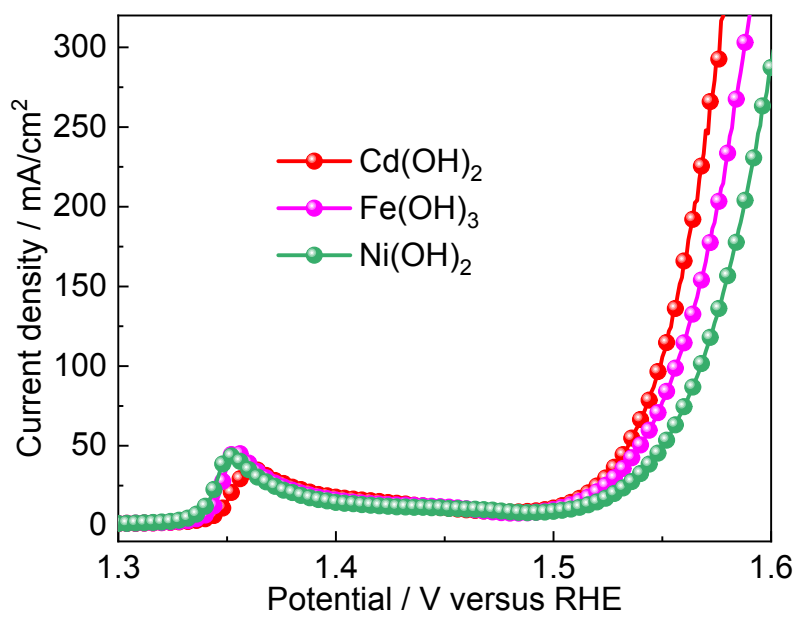

Figure S11. LSV curves of $\mathrm{Cd}(\mathrm{OH})_{2}, \mathrm{Fe}(\mathrm{OH})_{3}$ and $\mathrm{Ni}(\mathrm{OH})_{2}$ prepared by the same method. 
S13. CV curves of $\mathrm{Cd}(\mathrm{OH})_{2}$ and $\mathrm{Co}(\mathrm{OH})_{2}$ at different scan rates.
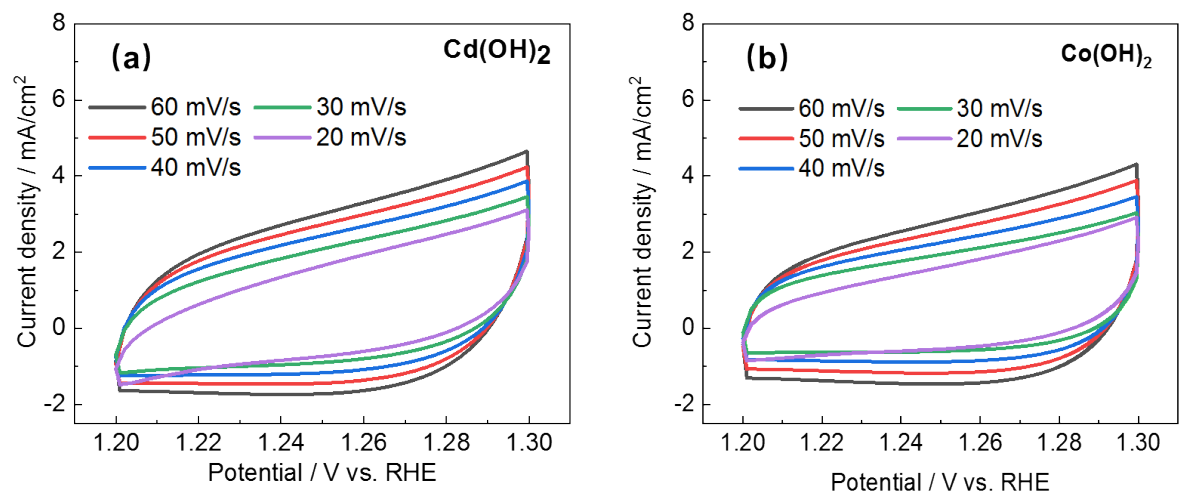

Figure S12. CV curves of (a) $\mathrm{Cd}(\mathrm{OH})_{2}$ and $(\mathrm{b}) \mathrm{Co}(\mathrm{OH})_{2}$ in $1.0 \mathrm{M} \mathrm{KOH}$ solution at different scan rates.

\section{Supplementary references}

S1. Kresse, G., VASP. 2014: http://cms.mpi.univie.ac.at/vasp/vasp/vasp.html.

S2. Kresse, G. and J. Furthmuller, Efficient iterative schemes for ab initio total-energy calculations using a plane-wave basis set. Phys. Rev. B: Condens. Matter, 1996. 54(16): p. 11169-11186.

S3. Kresse, G. and D. Joubert, From ultrasoft pseudopotentials to the projector augmented-wave method. Phys. Rev. B: Condens. Matter, 1999. 59(3): p. 1758-1775.

S4. Blochl, P.E., Projector augmented-wave method. Phys. Rev. B: Condens. Matter, 1994. 50(24): p. 17953-17979.

S5. Perdew, J.P., K. Burke, and M. Ernzerhof, Generalized gradient approximation made simple. Phys. Rev. Lett. , 1996. 77(18): p. 3865-3868.

S6. Valdes, A., et al., Oxidation and photo-oxidation of water on TiO2 surface. Journal of Physical Chemistry C, 2008. 112(26): p. 9872-9879.

S7. Rossmeisl, J., et al., Electrolysis of water on oxide surfaces. Journal of Electroanalytical Chemistry, 2007. 607(1-2): p. 83-89. 